論 文

\title{
太陽電池アレイの部分陰影での等価モデルに関する考察
}

\author{
梶原 篤 ${ }^{1}$ ，原川 哲美 ${ }^{2}$ \\ 1 群馬産業技術センター，群馬県前橋市亀里町 884-1 \\ 2 前橋工科大学工学部システム生体工学科, 群馬県前橋市上佐鳥町 460-1
}

\section{Considerations on Equivalent Model for PV-Array under Partial Shading}

\author{
Atsushi Kajihara ${ }^{1}$ and Tetsumi Harakawa ${ }^{2}$ \\ ${ }^{1}$ Gunma Industrial Technology Center, 884-1 Kamesato-cho Maebashi,Gunma Prefecture 379-2147, Japan \\ ${ }^{2}$ Department of Information Science, Maebashi Institute of Technology. 460-1 Kamisadori-cho Maebashi, \\ Gunma Prefecture 371-0816, Japan \\ E-mail: kaji-a@pref.gunma.lg.jp,harakawa@maebashi-it.ac.jp
}

\begin{abstract}
The photovoltaic-cell(PV-cell) and natural energy production systems have been much attracted. Due to global warning, and extensive applications of solar power electric generation, defects on PV-cell under the partial shading become interesting technical issue. This paper investigates the equivalent circuit model and its characteristics under the partial shading condition. As a consequence the new MPPT (maximal power point tracking) method has been proposed for the sake of drastic energy generation improvement.
\end{abstract}

Keywords photovoltaic-cell(PV-cell), solar power, electric generation, partial shading

\section{1. はじめに}

地球温暖化, 京都議定書の発効, 原子力発電 の問題から再生可能エネルギー社会への転換, 従来のエネルギー利用から自然エネルギー一の転 換が叫ばれている。特に太陽光発電は, 商用電源 の行き届かない山奥や未開発の地域での電力源 として期待され，かつ普及しつつある。太陽光発電 システムを構成する太陽電池パネルでは, 太陽電 池セル単体では端子電圧も低く, 取出せる電力も 小さい。そこでセルを多数直列接続しバイパスダイ オードとブロッキングダイオードを備えた太陽電池
モジュール, さらにモジュール間を複数接続した太 陽電池アレイとして実用化されている。このような太 陽電池アレイで, 不均一日照条件下で動作させる 場合, 出力に複峰性を示すことが近年報告されて いる[1]。そのなかで部分陰影照射条件によっては, 出力特性が大きく異なってくることも報告されてい る[2]。このような条件下では, 最大電力点ではない 別の電力極大点で動作点が収束してしまう可能性 もある。また, 不均一日射条件にも対応できる最大 電力点追従 (MPPT)制御として, 太陽光発電システ ムの出力電圧を開放電圧から減少させていき, そ の間電力の值を走査して最大電力点を測定し, そ 
の最大電力点まで動作点を移動させるスキャンニ ング法をベースとした MPPT 制御法が提案されて いる[3]。さらに, このような条件下で発生電力量を 最大化する二段階 MPPT 制御法も提案されている [4]。本論文では，モジュールの直列接続について， 部分陰影を考慮した等価回路モデルを検討し, 従 来の特性の発生要因を明らかにすることを目的と する。そのために, 部分陰影条件下で複峰性を出 現する最小構成である太陽電池モジュールの2直 列接続した太陽電池アレイを用いてモデルの有効 性を確認する。太陽電池アレイを表現する方法は 古くは数式で表現したもの[5]や近年では数值計 算によるもの[6][7]があるが, 外部からみた特性の みを検討の対象としている。複峰性を表すときのア レイ内の電流経路からみた外部特性の合理的な 説明, アレイに内包する損失については明らかに する。つぎに, 1 つの方法であるが, 提案する動作 メカニズムに基づいて複鋒性の特性を有する太陽 光発電システムで従来損失となり取り出せていなか った電力を回収するための制御方式を提案する。

\section{2. 部分陰影下での等価回路モデル}

\section{1 光電池セルの等価回路モデル}

よく知られているように, 電流源と, ダイオードの 並列回路で太陽電池セルを表現する等価モデル がある[8]。図 1 にその回路モデルを示す。太陽電 池セルそのものである PN 接合ダイオードと, 光電 流源 $I_{L}$ からなっている。このモデルで, 太陽電池の 端子電圧 $V$ と, 太陽電池外部に流れ出寸電流 $I の$ 関係は(1)式で示している。

$$
I=I_{L}-I_{S}\left\{\operatorname{Exp}\left(\frac{q V}{k T}\right)\right\}-1
$$

ここで, 光電流 $I_{L}$ は, 太陽電池自身であるダイオ 一ドの逆飽和電流 $I_{S}$ と素子外部に流孔る電流 $I$ と に分流され, 逆飽和電流 $I_{S}$ は端子電圧 $V$ と素子の 温度 $T$ とによって決定される。ここで, $q$ とkは定数 で, それぞれ, $q$ は素電荷, $k$ はボルツマン定数で ある。

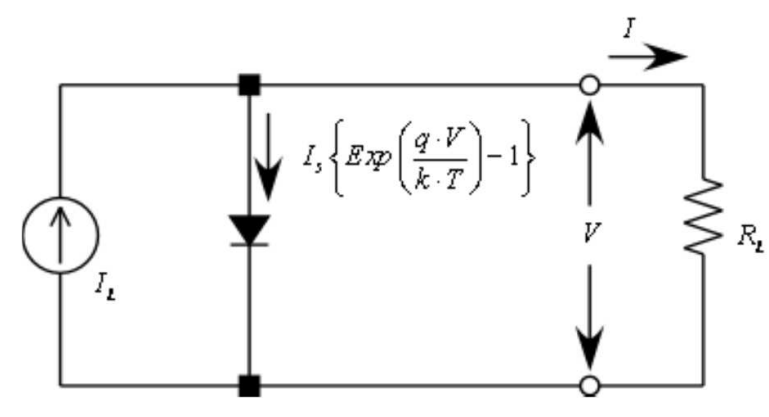

図 1 太陽電池セルの等価回路

Fig. 1 Model of PV-cell

\section{2 評価する太陽電池アレイのモデル}

本節では, 前節で述べた基本回路を発展させて, 太陽光の部分陰影下での特性を説明する等価回 路モデルを検討する。部分照射の特性を実現する ために, まず太陽電池アレイを $2 つ の$ 異なる照度を 受光するモジュールに分割し，その各々を前節の 等価回路で近似する。各モジュールは 7 個のダイ オードと電流源で構成した。複数のダイオードに対 して 1 つの電流源でモジュールを表現しているの は, 直列接続した太陽電池セルの中の最低の照 度すなわち電流值によって, モジュールの出力特 性が決定されるためである。すなわち, 太陽電池セ ルに光が当らず, その部分で発電していない場合 の電流の流路が確保されない。また, 個々のモジ ユール単体で複峰特性は出現しない。そこで, 太 陽電池セルと逆バイアスにダイオードを挿入する等 価回路を考える。その結果で得られる基本回路モ デルを図 2 に示す。

図 2 の構成では, 個々のモジュールに対し外部 からの電流の流入を防ぐために, モジュールに直 列に接続したダイオード (D16,D18) と, 電流源の 值が 0 , 即ち光照射が無いときの電流経路を確保 するためにそれらに並列に接続したダイオード （D15,D17）を挿入している。複峰特性が出現する 最低の構成は,このようなモジュールが2つ接続さ れ, かつ其々のモジュールに異なる照度の光照射 があった場合となると考えられる。

このモデルでの同一照射条件での電圧・電流特 性および電圧・電力特性を回路シミュレーションで 求めた結果をつぎに述べる。 


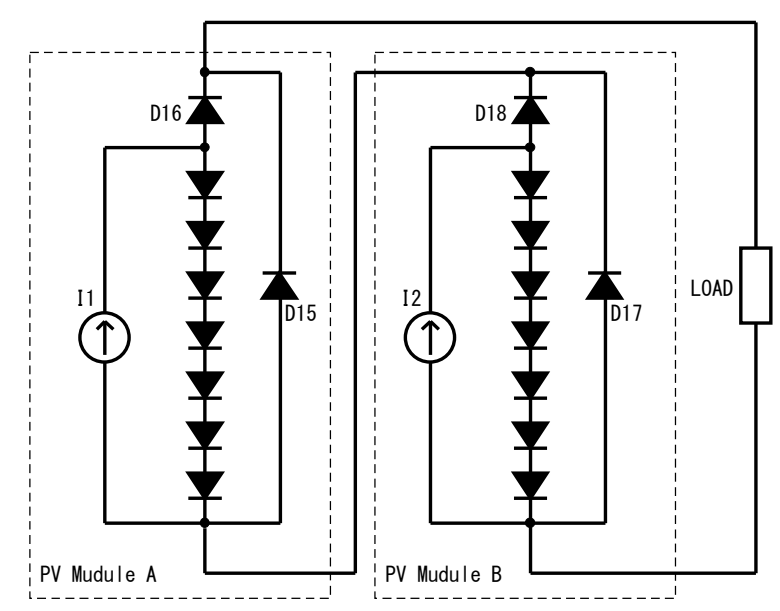

図 2 評価する太陽電池アレイの等価回路 Fig. 2 Model of connected PV-cell module

\section{3 直列接続太陽電池アレイの電流・電圧特性}

本節では, 図 2 のモデルを用いて均一光照射条 件, すなわち電流源 I1 および I2 の電流值を等し く, $20 \mathrm{~mA}$ 毎に $20 \mathrm{~mA}^{\sim} 100 \mathrm{~mA}$ で変化させ, 負荷に かかる, 電圧・電流特性および電圧・電力特性を 検討した。図 3 にその結果を示す。図 3 中で, 開 放端電圧から電圧上昇にかかわらず水平に移行 し, 短絡電圧付近で急激に電流值が低下している のが, 電圧・電流特性。山なりの形状に変化してい るのが, 電圧・電力特性を表している。ここで, 值の 低いほうから順に $20 \mathrm{~mA}$ 100mA のシミュレーション 結果を表している。これは, 典型的な太陽電池素 子とよく似た特性を示している。相違点は開放端 電圧付近の特性が異なっているが，これはそれぞ れのモジュールに直列に挿入したダイオードの影 響であると考えられる。図中縦軸は電流 (Y1)もしく は電力 (Y2)を示し, 横軸は出力端子電圧を示す。 さらに各カーブは照度を変化させたときの特性を

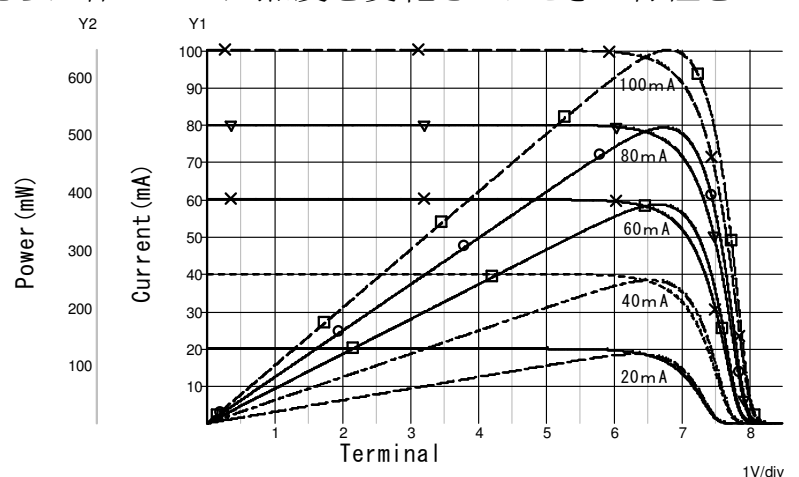

図 3 均一光照射の太陽電池モジュールの発電特性

Fig. 3 Electrical characteristics of PV module
示し,この結果は従来の太陽電池セルの特性と相 似形で一致していることが理解できる。

\section{3. 部分陰影下での太陽電池アレイの特性}

提案した太陽電池アレイを用いて, 部分陰条件 下での太陽電池アレイの電気特性を検討する。こ こでは図 2 のモデルで一方の電流源の值 (I1)を $100 \mathrm{~mA}$ 一定值とし, 他方の電流源 (I2)の值を変化 させ，前節と同様に, 電圧・電流, 電圧・電力特性 を求めた。このときの照度に関するシミュレーション 条件を表 1 に示す。

等価モデルでは，照射された光エネルギーを電 流源で表現していることから，等価的に照度を電 流源の值で記述した結果を表に記載する。また I1 は直列接続の Module A の電流源を, また I2 は Module B の電流源の值を示す。そのシミュレーショ ン結果を図 4 に示す。

シミュレーション結果は, 簡便化のために実際の 太陽電池アレイに存在する内部抵抗などを省略し て表現しているが, 出力電力特性の複鋒性を表現 できている。ここでは, 片方のモジュールの電流值 を固定し，他方を 6 段階の值でシミュレーションを 行った結果を示している。その時, 変化した電流值 に応じて, 最大電力点の值が変化している様子が よくわかる。これらの中で, 12 の值が, $40 \mathrm{~mA}$ のとき 二つの電力極大点の電力值がほぼ等しくなってい る。この電流比を境に, 高電圧の電力極大点と, 低電圧のそれとで最大電力点が入れ替わっている ことが確認できる。すなわち I2 の電流值が大きい 場合，高電圧側の電力極大点の電力が大きく, 小 さい場合は, 低電圧側の電力極大点の電力が大 きくなっている。

続いて, 比較のため実際の太陽電池パネル (図 5)を太陽光の下で特性を測定した，写真及び特 性図を図 6 に示す。測定した太陽電池パネルは, GOLDMASTER 社製\#738 SM1000-12V-FPで, 多 結晶シリコン太陽電池セルを 18 直列したパネルを さらに 2 直列し，合計 36 直列したものを 1 モジュー ルとして,バイパスダイオードを挿入し, 2 モジュー ルを直列接続したものである。快晴時に測定し，片 方のパネルに何段階かに角度をつけて照射光量 
表 1 部分陰影時のシミュレーション条件

Table 1 Conditions for serial connection

\begin{tabular}{|c|c|c|}
\hline & I1 (mA) & $\begin{array}{c}\text { I2 } \\
(\mathrm{mA})\end{array}$ \\
\hline 1 & 100 & 0 \\
\hline 2 & 100 & 20 \\
\hline 3 & 100 & 40 \\
\hline 4 & 100 & 60 \\
\hline 5 & 100 & 80 \\
\hline 6 & 100 & 100 \\
\hline
\end{tabular}

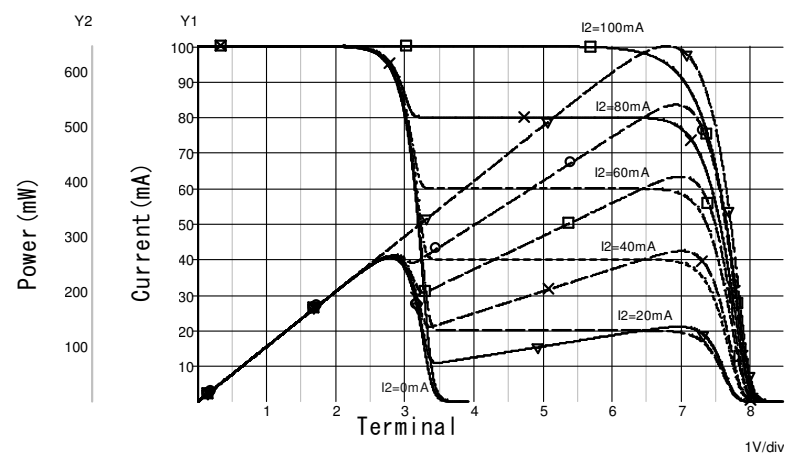

図 4 部分陰影下での縦続形太陽光節の発電特性

Fig. 4 Electrical characteristics of serially connected array under partial shading condition

を調節し不均一照射条件を表現した。実験では散 乱光の影響などで, 思うように照射する太陽光の 強度を調節できなかったが, 実際の太陽電池パネ ルでもシミュレーションと同様の電力複峰性を確認 できた。

このように, 実際に測定した2直列の太陽電池パ ネルとシミュレーションモデルの特性図を比較して もほぼ同様の特性を持っていることが確認できた。

\section{4. 複数の電力極大点の発生メカニズムと損失}

図 7 に図 2 の太陽電池アレイのモデルを用いた, 電力極大点が複数発生した特性図を示す。この特 性図は, Module Aの電流源に 100mA, Module B に 40mA の条件としている。このときの低電圧の最 大電力点の電力は約 $261 \mathrm{~mW}$, 高電圧の最大電力 点では約 $273 \mathrm{~mW}$ となっている。ちなみに, Module B の電流源を 0 とした時の最大電力は約 $260 \mathrm{~mW}$, Module A の電流源を 0 とした時は約 $100 \mathrm{~mW}$ とな る。つまり, 同一条件でそれぞれのモジュールを単 独で動作させたとき, それらの合計電力は, 約 $360 \mathrm{~mW}$ 得られるはずとなる。ところが, この特性図

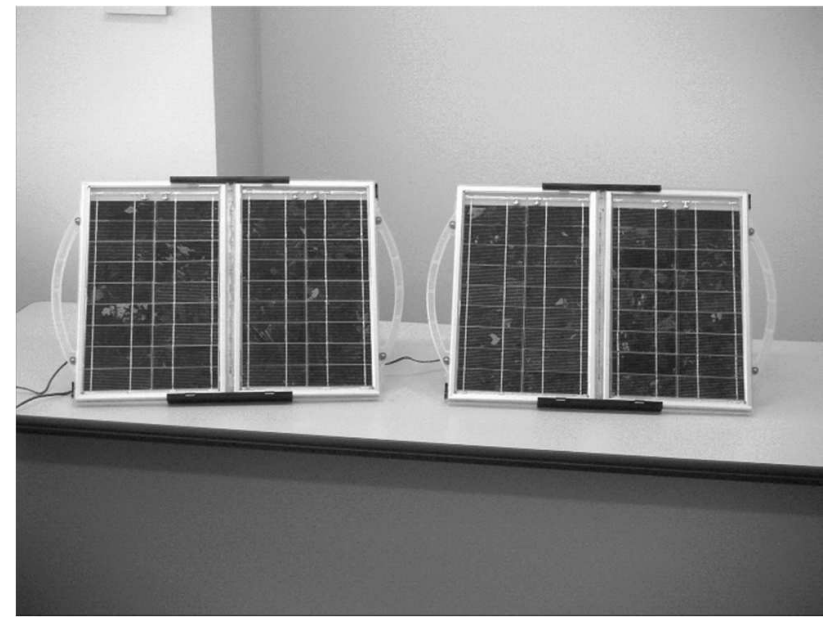

図 5 実験装置外観

Fig. 5 PV-panels used in experiment

I-V Character

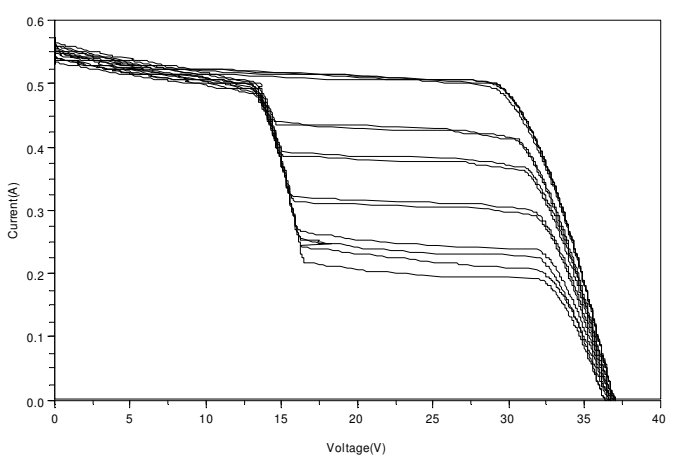

P-V Character

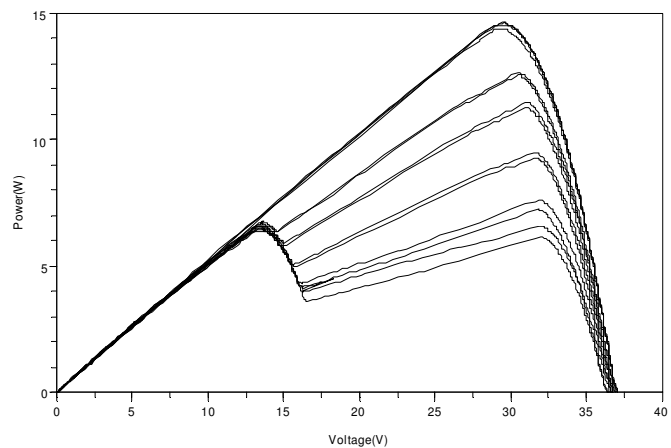

図 6 部分陰影条件下での発電特性の実験結果

Fig. 6 Measured PV-panels and their electrical characteristics

ではどちらの電力極大点においても, 合計電力に は及ばない。むしろ, Module B の電力はまったく取 り出せていないということがいえる。

このような現象が発生する原因を考察すると,

図 7 において, 低電圧の電力極大点で太陽電池 アレイが動作するとき電力は, 電圧 $\times$ 電流であるか ら, 電圧・電流特性の $\mathrm{OABC}$ の領域の面積分の電 


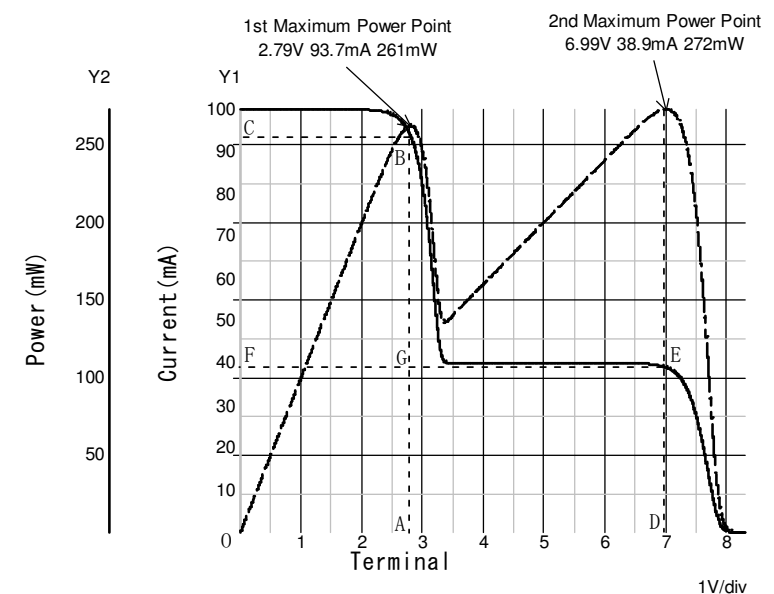

図 7 太陽光セル内の内部損失の説明図

Fig. 7 Loss possibility when two or more electric power maximum points are generated

力を取り出していることになる。

このとき, 図 8 のモデル上で電流は実線の経路 を流れているものと考えられる。なぜならば, その点 では電流值が約 $100 \mathrm{~mA}$ 流れるが, Module B の電 流源は $40 \mathrm{~mA}$ の電流しか流す能力が無く, そのダ イオードとしての太陽電池セルは逆バイアスで電流 を流せない。このとき $100 \mathrm{~mA}$ の電流は太陽電池セ ルと並列に接続された, 順バイアスのダイオードを 流れることになる。結果, Module A の太陽電池セ ルの分の電圧しか出力に現れないことになる。

続いて, 高電圧の電力極大点では, ODEF の領 域の面積分の電力といらことになる。このときは，

図 8 のモデル上で, 電流は点線の電流経路を流 れると考えられる。つまり, 電流值が減少し, 約 40mA まで減少したため, Module B の電流源でも 電流を流すことが可能となったため, それぞれのモ ジュールの太陽電池セルを電流が流れ, 結果それ ぞれの太陽電池セルの電圧が出力に現れたもの である。

ここで, 低電圧の電力極大点に動作点があると すると, そのとき, ADEG の領域の面積分の電力が 取り出せないことになる。同様に, 高電圧の電力極 大点に動作点があるとすると, FGBC の領域の面 積分の電力が取り出せない。この外部に取り出せ ない領域の電力は, 太陽電池アレイ内部で損失と なり, 熱を発生させる。すなわち, その部分での温 度上昇となると考えられる。

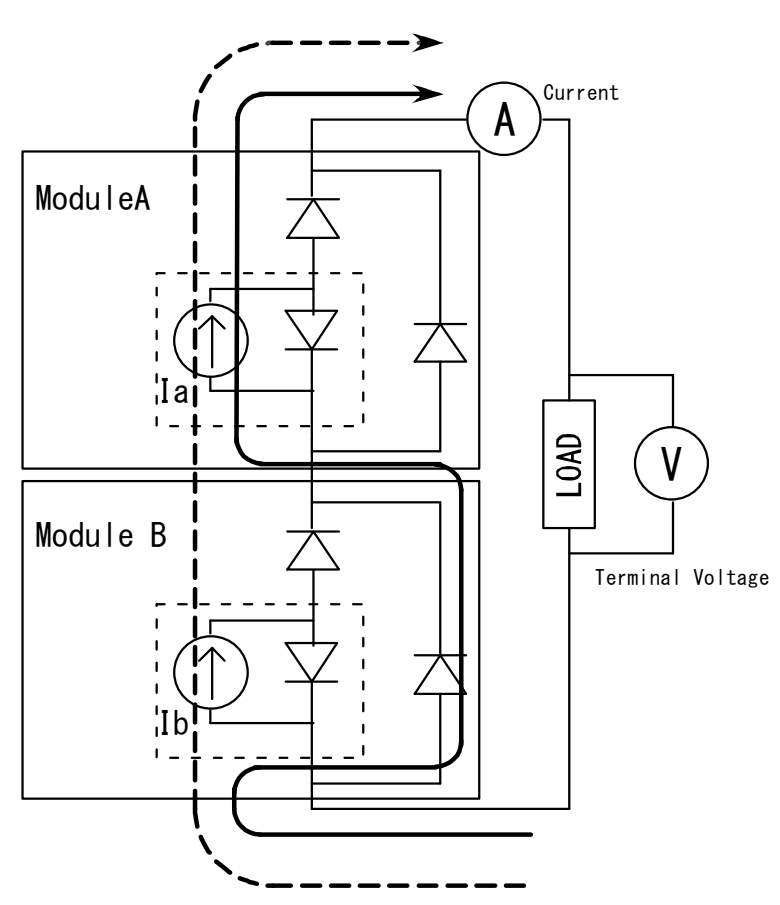

図 8 部分陰影下でのセル内電流の経路

Fig. 8 Current pass of PV-panels

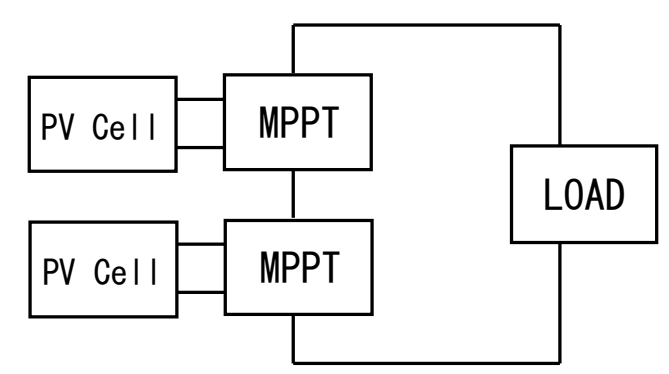

図 9 内部損失を補償する制御方式の提案

Fig. 9 Individual MPPT control block

\section{5. 部分陰影下での最大電力追従制御方式の提案}

このように直列方式の太陽電池アレイでは, 部 分陰影の日照条件を考慮すると, 従来の MPPT 制 御では十分な特性を実現できないことが明らかとな った。そこで, 直列 2 モジュールの太陽電池アレイ で，両制御方式の特性比較を試みる。具体的には 同一照度条件で,一括MPPT制御を行った場合 の発生電力と, 2 セルの独立 MPPT 制御による発 生電力の比較を行う。

このときの制御ブロックを図 9 に示す。

それぞれ, 表 1 と同様に Module A の光電流を 
100 とし, Module B の光電流を 0 から 100 まで変 化させたとき, 電力発生量の比較した結果を図 10 に示す。

図 10 の左軸は発生電力, 右軸は電力の比較, 横軸は Module B の光電流を示す。この図から 2 つ のセル間で 100:40 近傍時に, 発生電力に大きな 違いが生じていることが判明した。その従来比と比 べると, その改善量は約 60\%にもなることが判明し た。また光照度 $0: 100$ 及び $100: 100$ の条件では, 従来の一括 MPPT 制御と独立 MPPT 制御方式で は同じ特性を示すことから, 従来方式以上の性能 を実現できるものと推測される。

提案する独立 MPPT 制御方式は, モジュール毎 にMPPT 制御を実現するもので, LSI 化が容易と思 われる。

以上のことから, 提案する方式の実現可能性を 検討することが課題と思われる。

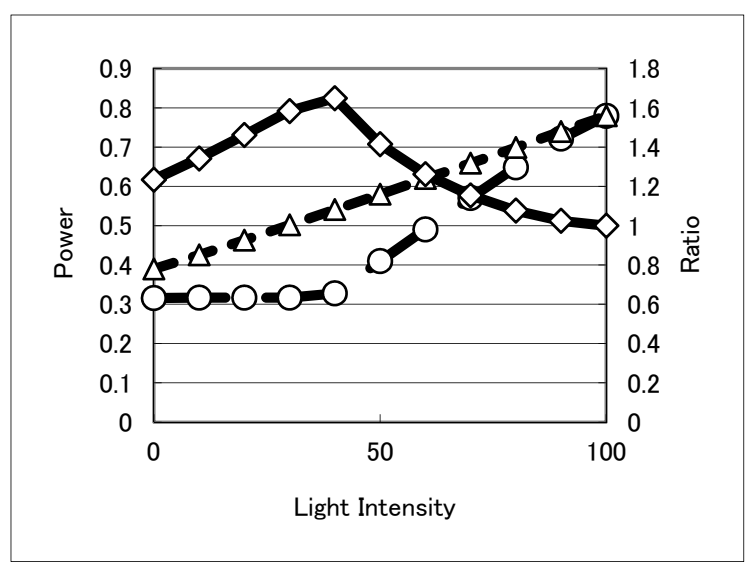

図 10 独立制御方式での発電特性実験結果 $\diamond$ と実線は従来方式との比較結果 $\triangle$ と破線は独立制御方式

○と破線は従来の単一制御方式

Fig. 10 Effect of proposed individual MPPT method

The upper row solid line marks show a comparative result.

The inside broken line marks for independent MPPT control.

The lower broken line marks for conventional MPPT control.

\section{6. おわりに}

太陽光発電システムは, 地球環境問題の高まり と共に実用化が進められている。近年, 部分陰影
等の不均一照射条件下での発電特性が注目され ている。本論文では，近年報告された部分陰影下 での発電特性の解明を元にこの条件での等価回 路モデルを提案した。そのモデルを用いて特性の シミュレーションおよび実際の太陽電池パネルを用 いた実験を通じて以下の知見を明らかにした。

（1）太陽電池アレイの直列接続で, 部分陰影によ って照射量が異なる場合, 発電量特性に複峰 性が現れる。次に直列接続のモジュール構成 で, 部分陰影下の検討を行った結果, 同じく複 峰性の特性が現れることを確認した。これらの 特性は従来報告された結果と同じであり，検討 したモデルの有効性を示すものと思われる。

（2）太陽電池アレイが部分影条件下におかれ，複 峰性が表れるメカニズムを考察し推測した結果, 複峰性が見られるとき, 太陽電池アレイ内部で 大きな電力損失が発生し, 温度上昇などの悪 影響があることを示した。

（3）2つの太陽電池モジュールによる直列接続で, 従来の MPPT 制御を行ったときと, 各々のセル 毎に独立 MPPT 制御を行ったときの発電量の 推移を検討した。この結果は, 約 60\%の特性改 善効果が見込まれることが判明した。しかもそ の改善量は最も出現しうる大きな部分陰影条 件で発生することを確認した。

本論文で検討した結果, ある程度の太陽電池モ ジュール毎に, MPPT 制御ブロックをLSI でパネル に組み合わせることで，均一照射条件で従来の MPPT 制御の特性と等価な特性を得られ,かつ大 きな不均一照射でその特性を大幅に改善できると 考えられる。MPPT 制御をLSI 化してパネルに組み 込むことを今後検討する予定である。また独立 MPPT 制御方式でのパネルの温度特性変化による 影響の検討を行う必要があると思われる。

\section{参考文献}

[1] 小林健二，鷹野一朗, 沢田芳夫: 部分陰条 件下における太陽光発電システムの二段階 MPPT 制御に関寸る検討, 電学論 D, Vol.124, No.8, pp.774-783, 2004.8.

[2]竹谷是幸:部分的影及びミスマッチによる太陽 
光発電装置における電力損失, 電磁環境工 学情報, No. 282, pp.104-110, 2011.10.

[3] 上田一敬, 鷹野一朗, 沢田芳夫: 不均一日 射条件時における複数アレイ PV システムの MPPT 制御, 電気学会半導体電力変換研究 会資料, SPC-04, 2004. 1.

[4] C. Hua and J. Lin: An on-line MPPT algorithm for rapidly changing illuminations of solar arrays, Renew Energy, Vol.28, No.7, pp. 1129-1142, July 2003.

[5] H. S. Rauschenbach: Electrical output of shadowed solar arrays, IEEE Trans. Electron Devices, Vol. ED-18, No.8, pp. 483-490, August 1971.

[6] Q. -S. Xu, L. L. Lai, N. Tse and K. Ichiyanagi: Hybrid behaviors analysis of photovoltaic array performance, Proceedings of 8th International Conference on Machine Learning and Cybernetics, pp. 3448-3456, 2011.

[7] H.Ziar, S.Mansourpour, A.Arjhangmehr, A.Salimi and E.Afjei : Analysis of thermal effect on solar cells with considering bypass diodes at shadow condition through binary coding method, Conference on Electric Power and Energy Conversion Systems (EPECS 2011), 2011.

[8]深海 登世司: 半導体工学, 東京電機大学出 版局, 2004.7.

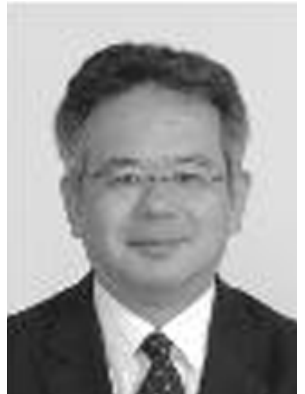

梶原 篤 1989 年 3 月金沢 工業大学工学部電子工学科卒 業。同年三菱電機ホーム機器 (株) 入社, 2001 年群馬県庁に 入庁, 群馬県立東毛産業技術セ ンター 技術支援係, 独立研究 員。現在企業向けの技術支援に 従事。2008 年前橋工科大学大学 院工学研究科システム情報工学 専攻博士前期課程修了。現在，同 後期課程在学中。

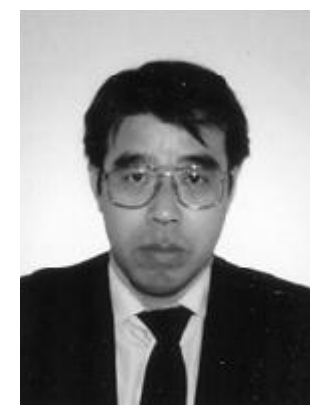

原川 哲美 1978 年九州大 学大学院工学研究科情報工学修 士課程修了。同年新日本製鐵(株) に入社。1999年退社。2001 年前 橋工科大学工学部情報工学科教 授，2007 年工学部システム生体 工学科教授, 現在に至る。知能制 御システム, 人工知能, 非線形信 号処理，医用画像理，CAD 関係 に興味を持つ。博士 (工学), 電 気学会, 計測自動制御学会, IEEE 会員。

\section{（2012 年 8 月 21 日受付； 2023 年 1 月 24 日再受付）}

